\title{
Kandungan Flavonoid dan Serat Sesbania grandiflora pada Berbagai Umur Bunga dan Polong
}

\author{
Flavonoid and Dietary Fiber Contents of Sesbania grandiflora at Different \\ of Flower and Pod Ages
}

Eko Setiawan

Diterima 13 Januari 2018/Disetujui 22 Mei 2018

\begin{abstract}
The vegetable production in Madura islands is very limited due to dry soil conditions. The turi tree (Sesbania grandiflora) planted in Madura as barrier rice fields has the potential to be optimized as a source of vegetable. The objective of the study was to determine flavonoid and dietary fiber contents in flowers and fruits/pods of red and white turi that are picked at different ages. The research was conducted in December 2016 to March 2017 at Bangkalan. The study was arranged is Completely Randomized Design method with two factors and three replications. First factor was namely flower (red and white turi), and second factor is harvest time (turi flowers are harvested at 1, 2, 3, 4, 5, and 6 days; while the fruits/pods are harvested at 1, 2, 3, 4, 5, and 6 weeks after anthesis). The results showed that flavonoid contents in white turi flower ranged from $12.58-211.35 \mathrm{mg} .100 \mathrm{~g}^{-1}$, whereas flavonoid contents in red flower ranged from 17.32- $30.05 \mathrm{mg} .100 \mathrm{~g}^{-1}$. The highest flavonoid content is produced at 4-day-old flowers for white turi, and 4-5 day-old flowers for red flowers. The dietary fiber content in turi flower was higher in red than white flower ranged from 2.11-2.85\% and 1.82$2.55 \%$, respectively. The amount of dietary fiber in the fruits/pods was low, range from 0.013-0.686\% and 0.009-0.722\% in white and red turi, respectively. The flowers of turi should be consumed at 4-5 day-old flowers, while fruits/pods at 1-3 weeks after anthesis.
\end{abstract}

Keywords: anthesis, functional vegetable, harvest time, Madura island

\begin{abstract}
ABSTRAK
Produksi tanaman sayuran di Pulau Madura sangat terbatas karena kondisi tanah yang kering. Pohon turi (Sesbania grandiflora) yang ditanam sebagai pembatas tegalan dan sawah di Madura berpotensi untuk dioptimalkan sebagai sumber bahan sayuran. Penelitian bertujuan mengetahui kandungan serat dan flavonoid pada bunga dan buah/polong turi warna merah dan putih yang dipetik pada umur yang berbeda. Penelitian dilaksanakan di Bangkalan pada bulan Desember 2016 sampai Maret 2017. Penelitian menggunakan Rancangan Acak Lengkap dengan dua faktor dan diulang 3 kali. Faktor pertama adalah jenis bunga (turi bunga merah dan bunga putih), sedangkan faktor kedua adalah umur panen (bunga turi dipanen pada umur 1, 2, 3, 4, 5, dan 6 hari; sedangkan buah (polong) dipanen pada umur 1, 2, 3, 4, 5, dan 6 minggu setelah bunga mekar). Hasil penelitian menunjukkan kandungan flavonoid pada bunga turi putih berkisar antara $12.58-21.35 \mathrm{mg} .100 \mathrm{~g}^{-1}$, sedangkan pada turi bunga merah kandungan flavonoid berkisar 17.32-30.05 mg.100 g $\mathrm{g}^{-1}$. Kandungan flavonoid tertinggi dihasilkan pada bunga umur 4 hari untuk turi putih, dan bunga umur 4-5 hari untuk turi merah. Kandungan serat turi merah lebih tinggi dibandingkan dengan turi putih masing-masing dengan kisaran antara $2.11-2.85 \%$ dan $1.82-2.55 \%$. Kandungan serat pada buah/polong turi sangat rendah berkisar antara $0.013-0.686 \%$ pada turi putih dan sebesar $0.009-0.722 \%$ pada turi merah. Bunga turi sebaiknya dikonsumsi pada umur 4-5 hari, sedangkan buah/polong pada umur 1-3 minggu setelah anthesis.
\end{abstract}

Kata kunci: anthesis, Pulau Madura, sayuran fungsional, umur panen 


\section{PENDAHULUAN}

Sesbania grandiflora L. (Fabaceae) banyak ditanam di pekarangan dan oleh masyarakat lebih dikenal sebagai tanaman turi, berfungsi sebagai tanaman hias, dimanfaatkan sebagai tanaman obat dan juga sayuran (Joshi et al., 2016; Kumar et al., 2008). Turi tersebar di wilayah Indonesia, Malaysia, Philipina, dan India. Tanaman ini banyak ditanam di kebun pekarangan, di pinggir jalan, serta di pematang sawah dan tegalan sebagai tanaman pembatas kepemilikan lahan (Bhoumik et al., 2016). Bagian tanaman turi seperti daun, bunga dan polong selain sebagai sayuran juga sumber bahan baku obat anemia, batuk, penurun panas, sebagai stimulasi kecerdasan, dan di Jawa biasa dipakai sebagai obat lambung (Kumar et al., 2008). Jus dari bunga turi dilaporkan bermanfaat sebagai expectorant dan daunnya sebagai anti bakteri (Padmalochana dan Rajan, 2014). Kandungan kimia dari tanaman turi diantaranya arginine, cystine, histidine, isolucine, phenylalanine, tryptophan, valine, threonine, alanine, aspargine, asam aspartic, saponin, asam oleat, galactose, rhamnose, asam glucuronic, flavonoid, dan kaempfrol (Bhoumik et al., 2016). Salah satu kandungan antioksidan yang tinggi dari tanaman turi adalah tanin dan flavonoid (Panda et al., 2013). Sayuran bunga adalah sayuran tradisional yang diambil dari tanaman sayuran khususnya bagian bunga yang dimasak dan dipercaya mempunyai khasiat kesehatan, dan jika teratur mengkonsumsi akan bisa menyembuhkan atau menghindari penyakit (Sathasivam dan Lakshmi, 2017). Di Rasashastra, India, pucuk daun turi, bunga, dan buah hijau yang masih muda dimakan terpisah atau juga sebagai salad dan campuran kare (Arunabha dan Satish, 2015). Sayuran bunga mengandung beberapa kandungan kimia seperti kelompok flavonoid, anthraquinone dan glycoside. Flavonoid adalah komponen penting yang terdapat pada bunga turi, berperan dalam aktivitas penghambatan mikroba (Arunabha dan Satish, 2015), selain itu turi juga mengandung tanin dan beberapa nutrisi serta astringent alami (Vinothini et al., 2017). Tanaman turi juga sebagai antioksidan potensial, kaya vitamin $\mathrm{A}$, vitamin $\mathrm{C}$, thiamine, riboflavin, dan nicotinic acid sehingga dapat melindungi manusia dari bahaya oksidasi (Ramesh et al., 2015).
Masyarakat Madura dikenal kurang suka mengkonsumsi sayuran. Rendahnya konsumsi sayuran tersebut salah satunya disebabkan oleh terbatasnya sayuran yang ditanam oleh masyarakat akibat keterbatasan air di Pulau Madura. Tanaman turi di Pulau Madura berpotensi dioptimalkan sebagai salah satu sumber sayuran karena banyak dibudidayakan sebagai pembatas tanah di lahan sawah atau tegalan, disamping dimanfaatkan sebagai sumber hijauan pakan ternak dan sebagai pupuk hijau (Setiawan, 2013). Daun turi banyak mengandung nitrogen yang bisa membantu kesuburan tanah; bunga dan buah pada musimnya dipanen dan dimanfaatkan sebagai sayuran (Mardhiyetti et al., 2014).

Umur panen merupakan salah satu faktor yang menentukan kualitas bunga dan buah, karena bunga turi dipanen saat berbentuk sabit dan ada yang sudah mekar dengan sempurna seperti halnya kupu-kupu, sedangkan buah atau polong yang dipanen masih lunak karena apabila dipanen terlalu tua akan mengeras. Turi termasuk sayuran indigenus untuk memenuhi kebutuhan sayuran rumah tangga masyarakat Pulau Madura. Tanaman turi sebagai sayuran indigenus karena dikenal masyarakat dan sudah terbiasa dikonsumsi, disukai anggota keluarga, ketersediaan dan kemudahan mengolah (Santosa et al., 2015). Bagian yang digunakan adalah pucuk daun, bunga dan buah/polong (Setiawan, 2017), dimasak dengan cara direbus bersama sayuran lain, dikonsumsi sebagai lalapan atau salad (Saifudin et al., 2016). Bunga turi berwarna pink, merah dan putih (Siddhuraju et al., 2014).

Penentuan umur panen yang tepat diperlukan untuk menjaga kualitas sayuran yang akan dikonsumsi terutama kandungan serat dan flavonoid yang diharapkan. Penelitian ini penting dilakukan untuk mengetahui kandungan serat dan flavonoid pada bunga dan buah/polong turi warna merah dan putih yang dipetik pada umur yang berbeda. Hasil penelitian ini dimanfaatkan untuk memetik sayuran berkualitas secara tepat waktu dan menghindari kehilangan sayuran akibat menurunnya mutu sayuran.

\section{BAHAN DAN METODE}

Tanaman turi yang digunakan adalah tanaman berbunga merah dan putih masing- 
masing sebanyak 12 pohon. Tanaman turi yang digunakan untuk penelitian berumur \pm 2 tahun dan sudah pernah berbunga. Penelitian dilakukan pada bulan Desember 2016 sampai Maret 2017 di Bangkalan. Bunga turi dari kuncup sampai mekar memerlukan waktu 6 hari. Rancangan penelitian yang digunakan adalah Rancangan Acak Lengkap (RAL) terdiri atas dua faktor, pertama yaitu jenis turi berbunga putih dan merah dan faktor kedua adalah umur panen, yaitu panen pada bunga umur 1, 2, 3, 4, 5, dan 6 hari (Gambar 1), dan 6 perlakuan panen pada buah/polong umur 1,2 , $3,4,5$, dan 6 minggu setelah bunga mekar atau anthesis (Gambar 2) yang diulang 3 kali. Setiap ulangan terdiri atas 4 pohon, dari sejumlah cabang yang ada pada 4 pohon tersebut kemudian dipilih cabang/ranting yang ada kucup bunga secara acak dan diberikan label sebagai perlakuan umur panen (yaitu 12 perlakuan, terdiri 6 umur panen untuk bunga dan 6 umur panen untuk polong. Bunga dan buah/polong turi yang sudah dipanen selanjutnya dianalisis kandungan serat dan flavonoid yang diuji di Badan Penelitian dan Konsultasi Industri (BPKI) Surabaya.

Analisis uji serat dilakukan menurut SNI 01-2891-1992 (BSN, 1992) dengan cara $5 \mathrm{~g}$ sampel segar dari setiap perlakuan (bunga umur 1-6 hari, termasuk mahkota dan kelopak; buah/polong umur 1-6 minggu setelah anthesis) dimasukkan ke erlenmeyer, ditambahkan 100 $\mathrm{ml} \mathrm{H}_{2} \mathrm{SO}_{4}$ dan diaduk rata, kemudian didihkan selama 30 menit. Ditambahkan $200 \mathrm{ml} \mathrm{NaOH}$ dan didihkan lagi selama 30 menit, kemudian disaring, dikeringkan pada suhu $105{ }^{\circ} \mathrm{C}$, kemudian ditimbang. Setelah itu, endapan dicuci berturut-turut dengan menggunakan air panas dan alkohol. Selanjutnya, kertas saring dan endapan dikeringkan, diangkat dan dimasukkan ke dalam pijar, kemudian dikeringkan lagi pada suhu $105^{\circ} \mathrm{C}$ selama 1 jam sehingga bobot konstan.

Kadar serat kasar $=\frac{\mathrm{J}-\mathrm{Z}-\mathrm{X}}{\text { Bobot sampel }} \times 100 \%$

Dimana : $\mathrm{J}=$ Bobot kertas saring + isi + cawan $\mathrm{Z}=$ Bobot abu + cawan $\mathrm{X}=$ Bobot kertas saring

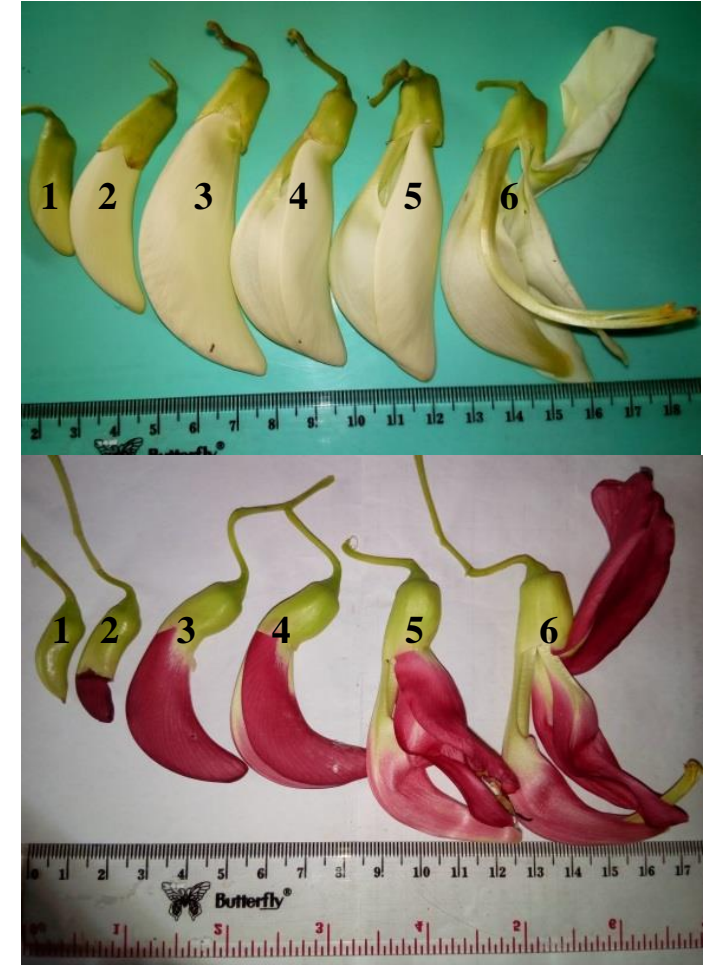

Gambar 1. Bunga turi putih (atas) dan bunga turi merah (bawah). Angka menunjukkan panen bunga umur 1 , 2, 3, 4, 5, dan 6 hari.

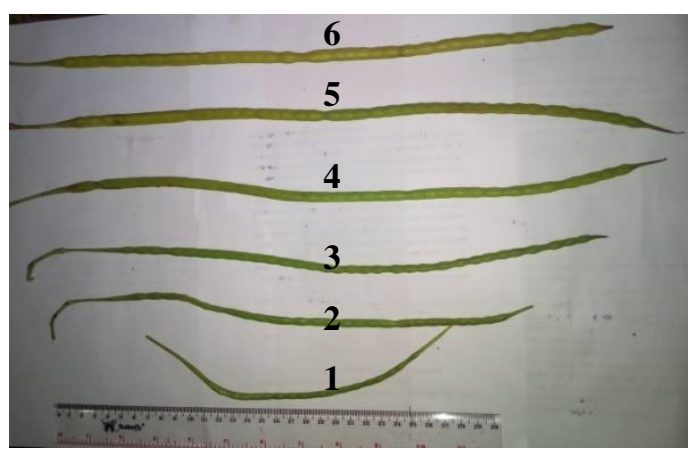

Gambar 2. Buah/polong yang dipanen. Angka menunjukkan panen buah/polong umur 1, 2, 3, 4, 5, dan 6 minggu setelah bunga mekar (anthesis).

Analisis uji kandungan senyawa flavonoid total menurut Padmalochana dan Rajan (2014) dilakukan dengan cara sebanyak $5 \mathrm{~g}$ sampel segar dari setiap perlakuan (bunga umur 1-6 hari, termasuk mahkota dan kelopak; buah/polong umur 1-6 minggu setelah anthesis) dihancurkan dan dimasukkan kedalam labu ekstraktor, ditambahkan $50 \mathrm{ml}$ benzena dan 50 
$\mathrm{ml}$ etanol, diekstrak selama 2 jam, setelah itu disaring hingga diperoleh filtrat jernih. Larutan standar flavonoid dibuat dengan pelarut benzena etanol. Larutan sampel dan larutan standar flavonoid diukur nilai penyerapan/ absorbansi dengan alat spektrofotometer UV Vis pada panjang gelombang $350 \mathrm{~nm}$ (China $e t$ al., 2012).

Kadar flavonoid

$$
=\frac{\text { Nilai absorsi sampel }}{\text { Nilai absorsi standar }} \times \text { Konsentrasi standar }
$$

Data yang diperoleh dianalisis menggunakan ANOVA. Apabila terdapat pengaruh perlakuan maka dilanjutkan menggunakan DMRT 5\%.

\section{HASIL DAN PEMBAHASAN}

Hasil penelitian menunjukkan bobot bunga sangat berbeda nyata antar umur petik. Bobot segar bunga turi putih berkisar antara 5.80-7.05 g, sedangkan bobot segar bunga turi merah berkisar antara 6.5-9.5 g per buah (Gambar 3). Bobot bunga turi meningkat dari hari pertama sampai hari ke tiga, tertinggi pada umur tiga hari kemudian menurun secara perlahan. Hal tersebut dikarenakan pada umur 5-6 hari sebagian bunga sudah mulai mekar, mahkota bunga akan layu dan rontok akibat penyerbukan selanjutnya terbentuk buah/ polong. Bobot bunga turi warna merah lebih tinggi dari bunga turi warna putih. Bobot segar buah/polong secara signifikan meningkat mulai minggu pertama sampai minggu kelima dan selanjutnya konstan. Tidak terdapat perbedaan yang nyata antara bobot buah/polong turi bunga merah dan putih (Gambar 4).

Hasil penelitian menunjukkan bahwa trend peningkatan kandungan flavonoid pada kedua jenis bunga turi mirip dengan bobot bunga. Kandungan flavonoid pada bunga turi putih meningkat dari umur 1-4 hari dan selanjutnya perlahan menurun sampai umur 6 hari (Gambar 5). Kandungan flavonoid pada bunga turi putih berkisar antara 12.58-21.35 mg. $100 \mathrm{~g} \mathrm{~g}^{-1}$. Kandungan flavonoid pada bunga turi merah meningkat dari umur 1-5 hari dan menurun pada umur 6 hari, dengan nilai berkisar antara 17.32-30.05 mg. $100 \mathrm{~g}^{-1}$. Secara umum, rata-rata kandungan flavonoid pada bunga turi merah lebih tinggi yaitu 24.89 mg.100 $\mathrm{g}^{-1}$ dibandingkan bunga turi putih dengan nilai $17.18 \mathrm{mg} .100 \mathrm{~g}^{-1}$.

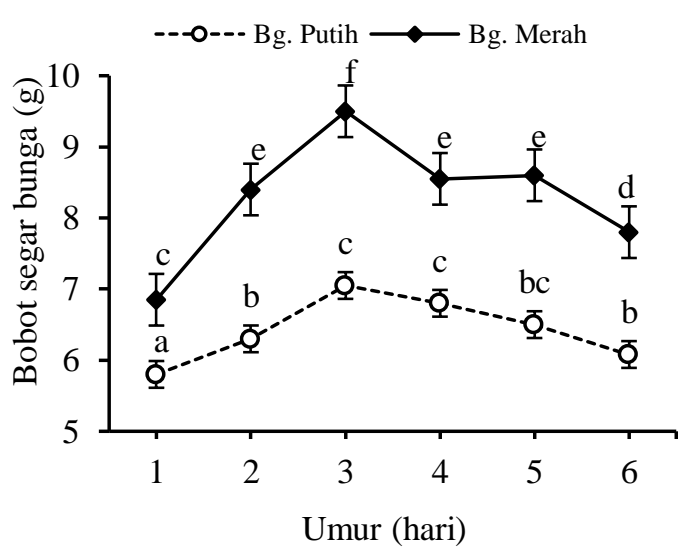

Gambar 3. Bobot segar bunga turi warna merah dan putih. Bar \pm SE.

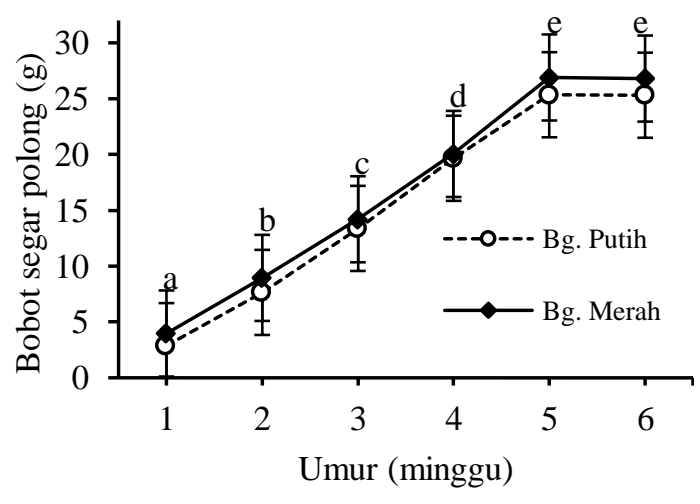

Gambar 4. Bobot segar buah/polong turi warna merah dan putih. Bar \pm SE.

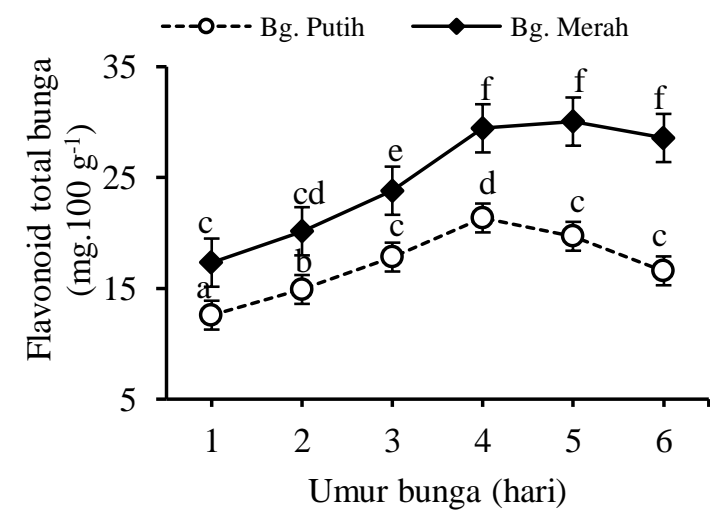

Gambar 5. Kandungan flavonoid total pada bunga turi warna merah dan putih. Bar \pm SE. 
Produksi flavonoid total sangat berhubungan dengan pigmen warna pada tanaman (Ghasemzadeh et al., 2010). Kandungan flavonoid pada bunga turi merah lebih tinggi, hal tersebut diduga karena pada bunga turi merah banyak mengandung anthocyanine, yaitu pigmen utama sebagai penyusun warna merah (Wang et al., 2009). Zhao et al. (2012) menyatakan flavonoid total terdiri atas unsur anthocyanine sebagai group utama serta gabungan dari chalcones dan anthoxanthine. Ghasemzadeh et al. (2010) menyatakan beberapa produk dari biosintesis kelompok phenol pada tanaman seperti anthocyanine dirubah menjadi flavonoid, sehingga pada bunga turi merah kandungan flavonoidnya lebih tinggi.

Hasil penelitian ini menunjukkan bahwa kandungan flavonoid total pada bunga turi merah sangat tinggi pada umur 4-5 hari dengan nilai 29.44-30.05 mg.100 $\mathrm{g}^{-1} \quad$ kemudian menurun menjadi $28.57 \mathrm{mg} .100 \mathrm{~g} \mathrm{~g}^{-1}$ pada umur 6 hari. Andarwulan et al. (2012) melaporkan kandungan flavonoid total pada bunga turi $21.23 \mathrm{mg} .100 \mathrm{~g} \mathrm{~g}^{-1} \mathrm{FW}$ terdiri atas quercetin dan kaempferol yaitu sebesar 2.6 dan $18.47 \mathrm{mg} .100$ $\mathrm{g}^{-1} \mathrm{FW}$, sedangkan kandungan myricetin, luteolin, dan apigenin tidak terdeteksi. China et al. (2012) menyatakan kandungan flavonoid yang paling dominan pada bunga turi adalah jenis rutin.

Hasil analisis kandungan flavonoid total pada buah/polong turi tidak berbeda nyata antara turi bunga putih dan turi bunga merah, masing-masing secara berurutan berkisar antara 0.011-0.436 mg.100 $\mathrm{g}^{-1}$ dan 0.010-0.402 mg.100 $\mathrm{g}^{-1}$ (Gambar 6). Peningkatan kandungan flavonoid terjadi seiring pertambahan umur buah atau polong. Pada buah/polong umur 5-6 minggu terjadi peningkatan kandungan flavonoid sebesar 4 kali lipat dari kandungan flavonoid pada umur sebelumnya, hal ini terjadi baik pada buah polong turi putih dan turi merah. Vinothini et al. (2017) menyatakan kandungan flavonoid tidak hanya terdapat pada bunga turi tetapi juga pada biji, yaitu saat pembibitan sekitar 21.51-22.22 mg. $\mathrm{g}^{-1}$, sedangkan pada daun turi kandungan flavonoid sebesar $7.0 \mu \mathrm{g} \cdot \mathrm{mL}^{-1}$ dengan solvent choloroform dan $22.5 \mu \mathrm{g} . \mathrm{mL}^{-1}$ dengan methanol (Lee et al., 2014). Total flavonoid pada daun Sesbania sesban dilaporkan berkisar antara 1.61 - 3.22 g QE.100 g ${ }^{-1}$ (Fitriansyah et al., 2017). Arya et al. (2013) menyatakan bunga turi tidak hanya mengandung flavonoid saja, tetapi juga kaya alkaloid dan phenol.

Kandungan serat sangat berbeda nyata antara bunga turi putih dan bunga turi merah (Gambar 7). Analisis serat pada bunga turi putih dan turi merah diperoleh hasil masing-masing berkisar antara $1.82-2.55 \%$ dan $2.11-2.85 \%$. Hasil penelitian menunjukkan bahwa kandungan serat pada bunga turi merah lebih tinggi, hal ini diduga berkaitan dengan kandungan pigmen warna merah pada bunga. Sesuai penelitian Gonçalves et al. (2016) pada Vigna unguiculata, bahwa varietas berpigmen mempunyai kandungan serat pangan dua kali lebih banyak daripada varietas yang tidak berpigmen. Perbedaan kandungan serat pangan pada legum jenis Vigna unguiculata bisa disebabkan oleh faktor genetik maupun faktor lingkungan (Asare et al., 2013).

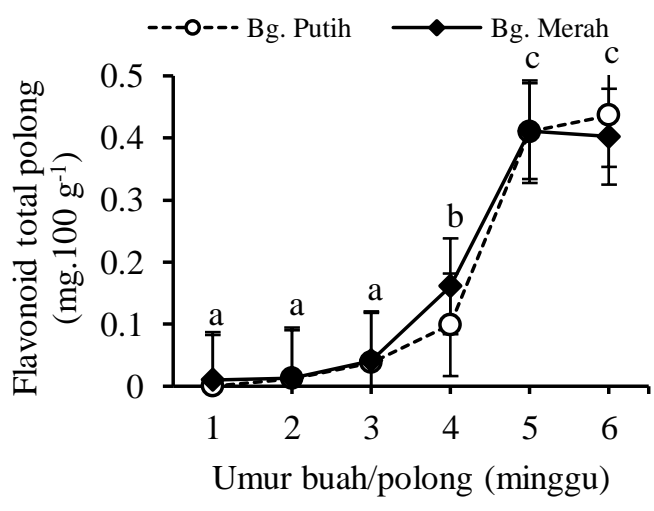

Gambar 6. Kandungan flavonoid total pada buah/polong dari turi warna merah dan putih. Bar \pm SE.

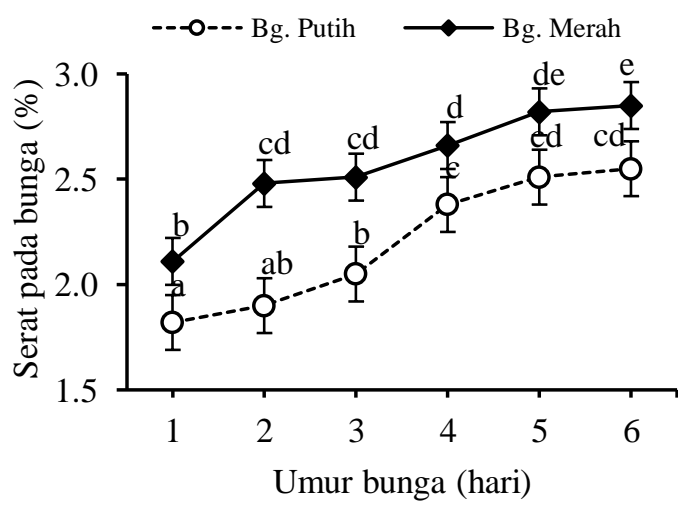

Gambar 7. Kandungan serat pada bunga turi warna merah dan putih. Bar \pm SE. 
Kacang-kacangan dan tanaman polong yang dapat dimakan adalah makanan yang kaya sumber serat makanan yang bermanfaat bagi kesehatan manusia (Tosh dan Yada, 2010). Dari hasil penelitian ini diketahui kandungan serat pangan pada bunga turi lebih tinggi dibandingkan dengan Vigna unguiculata yang mencapai 1.33-2.42\% (Owolabi et al., 2012); Cicer arietinum (1.1\%), Vigna unguiculata $\mathrm{L}$. Walp (1.0\%), dan Macrotyloma uniflorum L. (1.4\%) (Sreerama et al., 2012); setara dengan Lentil culinaris yang berkisar antara 2-7\% (Tosh dan Yada, 2010).

Jumlah serat pada buah/polong turi berkisar antara $0.013-0.686 \%$ pada turi putih dan sebesar $0.009-0.722 \%$ pada turi merah (Gambar 8). Hasil penelitian ini menunjukkan bahwa kandungan serat pangan pada buah/polong turi masih lebih tinggi daripada tanaman legume lainnya seperti Pisum sativum, Lima bean, dan Green bean yang mempunyai serat pangan berturut-turut sebesar $0.3,0.4$ dan 0.5\% (Dhingra et al., 2012). Jumlah serat pada buah/polong turi meningkat seiring dengan pertambahan umur, meskipun kandungan seratnya lebih rendah daripada bunga turi. Hal ini berarti buah/polong yang semakin tua akan semakin keras karena kandungan serat kasar semakin tinggi (Sreerama et al., 2012), seperti pada Cicer arietinum, Vigna unguiculata, Macrotyloma uniflorum L. yang berkisar 1314\%; sedangkan pada Lentil culinaris serat kasar mencapai 11-17\% (Tosh dan Yada, 2010). Girish et al. (2012) menyatakan pada kacang-kacangan variasi kandungan serat tak larut lebih tinggi yaitu antara 21-69\%, sedangkan kadar serat larut berkisar antara 2.6-9.3\%.

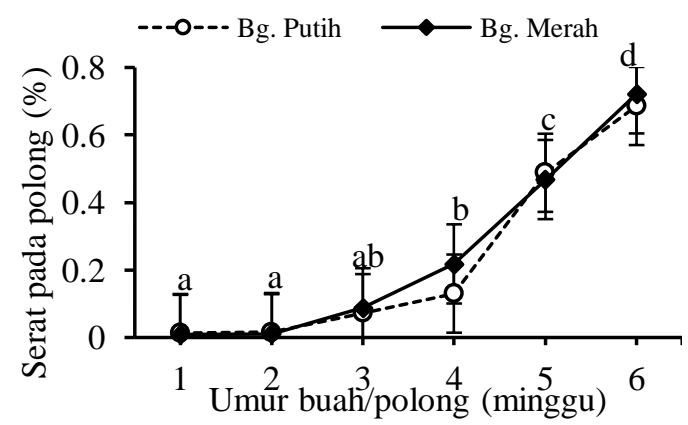

Gambar 8. Kandungan serat pada buah/polong dari turi warna merah dan putih. Bar \pm SE.

Dari hasil analisis kandungan serat pada buah/polong sebaiknya dipetik untuk dikonsumsi pada umur 1-3 minggu setelah anthesis (Gambar 8). Diduga buah/polong pada umur 1-3 minggu setelah anthesis mempunyai perbandingan serat pangan (soluble dietary fiber) dan kandungan serat kasar (insoluble dietary fiber) yang ideal sehingga tekstur sayuran tidak terlalu keras. Serat pangan terdiri atas polimer karbohidrat seperti dinding sel tanaman, selulosa, hemiselulosa, pektin, dan oligosakarida seperti inulin (Mudgil dan Barak, 2013); sedangkan serat kasar tidak dapat dicerna karena mengandung polisakarida, lignin, cutin, $\beta$-glukan, arabinoksylans, dan galactomannans (Saura-Calixto, 2011), fruktooligosakarida, galakto - oligosakarida, polydextrose, wax, saponin, polifenol, phytate, dan phytosterols (Mudgil dan Barak, 2013). Pugalenthi et al. (2004) melaporkan pada biji Sesbania bispinosa mempunyai kandungan serat total, protein kasar, dan lemak kasar berturut-turut sebesar $6.91,31.08$, dan 6.23 g.100 g-1. Serat pangan sering dipakai untuk pengembangan makanan fungsional (Zhu et al., 2014). Serat pangan memiliki peran dalam pencegahan penyakit kardiovaskular, kanker, dan diabetes (Girish et al., 2012). Serat pangan dapat memperbaiki profil lipid darah melalui efek penurunan kolesterolnya, menurunkan tekanan darah melalui pengurangan obesitas perut dan peningkatan reaktivitas vaskular, meningkatkan sensitivitas insulin, menghambat kenaikan postprandial glukosa dan trigliserida, meningkatkan aktivitas fibrinolitik, yang semuanya dapat mencegah atau menunda perkembangan atherosklerosis (Eshak et al., 2010). Keadaan kenyang dapat dicapai lebih cepat dan bertahan lebih lama setelah mengkonsumsi makanan berserat tinggi, karena lebih banyak dan memakan waktu lebih lama untuk dikonsumsi dan menunda pengosongan lambung (Bouchenak dan Lamri-Senhadji, 2013). Selain pada bunga, kandungan serat kasar yang tinggi dilaporkan Punna dan Paruchuri (2004) juga terdapat pada daun Sesbania grandiflora sekitar 8.4 g. $100 \mathrm{~g} \mathrm{~g}^{-1}$ yang berpotensi digunakan sebagai bahan campuran pakan ternak atau ikan (Hossain et al., 2002).

\section{KESIMPULAN}

Kandungan flavonoid pada bunga turi putih berkisar antara 12.58-21.35 mg.100 g-1, sedangkan pada turi bunga merah kandungan 
flavonoid berkisar antara 17.32-30.05 mg.100 $\mathrm{g}^{-1}$. Bunga turi sebaiknya dikonsumsi pada saat kandungan flavonoidnya optimal yang dihasilkan pada bunga umur 4 hari untuk turi putih, dan bunga umur 4-5 hari untuk turi merah. Buah/polong sebaiknya dipetik atau dikonsumsi pada umur 1-3 minggu setelah anthesis karena teksturnya tidak kasar.

\section{DAFTAR PUSTAKA}

Andarwulan, N., D. Kurniasih, R. Aris, H. Rahmat, A.V. Roto, B.W. Bolling. 2012. Polyphenols, carotenoids, and ascorbic acid in underutilized medicinal vegetables. J. Funct. Foods. 4(1): 339-347.

Arunabha, M., N. Satish. 2015. Study the immunomodulatory effects of combined extracts of Sesbania grandiflora flowers and Cocculus hirsutus leaves on the circulating antibody response. Am. J. Phytomed. Clin. Ther. 3(3): 199-208.

Arya, V., D. Kumar, M. Gautam. 2013. Phytopharmacological review on flowers: source of inspiration for drug discovery. Biomed. Prev. Nutr. 180: 1-7.

Asare, A.T., R. Agbemafle, G.E. Adukpo, E. Diabor, K.A. Adamtey. 2013. Assessment of functional properties and nutritional composition of some cowpea (Vigna unguiculata L.) genotypes in Ghana. ARPN J. Agric. Biol. Sci. 8(6): 465-469.

Bhoumik, D., A.H. Berhe, A. Mallik. 2016. Evaluation of gastric anti-ulcer potency of ethanolic extract of Sesbania grandiflora Linn leaves in experimental animals. Am. J. Phytomedicine Clin. Ther. 4(6): 174-182.

Bouchenak, M., M. Lamri-Senhadji. 2013. Nutritional quality of legumes, and their role in cardiometabolic risk prevention: a review. J. Med. Food. 16(X): 1-14.

[BSN]. Badan Standardisasi Nasional. 1992. SNI 01-2891. Cara Uji Makanan dan Minuman. Jakarta.
China, R., S. Mukherjee, S. Sen, S. Bose, S. Datta, H. Koley, P. Dhar. 2012. Antimicrobial activity of Sesbania grandiflora flower polyphenol extracts on some pathogenic bacteria and growth stimulatory effect on the probiotic organism Lactobacillus acidophilus. Microbiol. Res. 167(8): 500-506.

Dhingra, D., M. Michael, H. Rajput, R.T. Patil. 2012. Dietary fibre in foods: a review. J. Food Sci. Technol. 49(3): 255-266.

Eshak, E.S., H. Iso, C. Date, S. Kikuchi, Y. Watanabe, Y. Wada, A. Tamakoshi. 2010. Dietary fiber intake is associated with reduced risk of mortality from cardiovascular disease among Japanese men and women. J. Nutr. 140: 1445-1453.

Fitriansyah, S.N., I. Fidrianny, K. Ruslan. 2017. Correlation of total phenolic, flavonoid and carotenoid content of Sesbania sesban (L. Merr) leaves extract with DPPH scavenging activities. Int. J. Pharmacogn. Phytochem. Res. 9(1): 89-94.

Ghasemzadeh, A., H.Z.E. Jaafar, A. Rahmat, P.E.M. Wahab, M.R.A. Halim. 2010. Effect of different light intensities on total phenolics and flavonoids synthesis and anti-oxidant activities in young ginger varieties (Zingiber officinale Roscoe). Int. J. Mol. Sci. 11: 3885-3897.

Girish, T.K., V.M. Pratape, U.J.S.P. Rao. 2012. Nutrient distribution, phenolic acid composition, antioxidant and alphaglucosidase inhibitory potentials of black gram (Vigna mungo L.) and its milled byproducts. Food Res. Int. 46(1): 370-377.

Gonçalves, A., P. Goufo, A. Barros, R. Domínguez-perles, H. Trindade, E.A.S. Rosa, M. Rodrigues. 2016. Cowpea (Vigna unguiculata L. Walp), a renewed multipurpose crop for a more sustainable agri-food system: nutritional advantages and constraints. J. Sci. Food Agric. 96: 2941-2951. 
Hossain, M.A., U. Focken, K. Becker. 2002. Nutritional evaluation of dhaincha (Sesbania aculeata) seeds as dietary protein source for tilapia Oreochromis niloticus. Aquac. Res. 33: 653-662.

Joshi, A., A. Kalgutkar, N. Joshi. 2016. Value of floral diversity of the Sanjay Gandhi National Park (SGNP). Ann. Plant Sci. 5(2): 1276-1279.

Kumar, A.S., K. Venkateshwaran, S. Vanitha, M. Ganesh, M. Vasudevan, T. Sivakumar. 2008. Synergism between methanolic extract of Sesbania grandiflora (Fabaceae) flowers and oxytetracycline. Pharmacologyonline. 3: 6-11.

Lee, J.H., S. Cho, H.D. Paik, C.W. Choi, K.T. Nam, S.G. Hwang, S.K. Kim. 2014. Investigation on antibacterial and antioxidant activities, phenolic and flavonoid contents of some Thai edible plants as an alternative for antibiotics. Asian Australas. J. Anim. Sci. 27(10): 1461-1468.

Mardhiyetti, Z. Syarif, N. Jamarun, I. Suliansyah. 2014. Response same explant of turi (Sesbania grandiflora) in shoot induction medium. Int. J. Advaced Sci. Eng. Inf. Technol. 4(4): 30-32.

Mudgil, D., S. Barak. 2013. Composition, properties and health benefits of indigestible carbohydrate polymers as dietary fiber: a review. Int. J. Biol. Macromol. 61: 1-6.

Owolabi, A.O., U.S. Ndidi, B.D. James, F.A. Amune. 2012. Proximate, antinutrient and mineral composition of five varieties (improved and local) of cowpea, Vigna unguiculata, commonly consumed in Samaru community, Zaria-Nigeria. Asian J. Food Sci. Technol. 4(2): 70-72.

Padmalochana, K., M.S.D. Rajan. 2014. Antimicrobial activity of aqueous, ethanol and acetone extracts of Sesbania grandiflora leaves and its phytochemical characterization. Int. J. Pharma Sci. Res. 5(12): 957-962.
Panda, C., U.S. Mishra, S. Mahapatra, G. Panigrahi. 2013. Free radical scavenging activity and phenolic content estimation of Glinus oppositifolius and Sesbania grandiflora. Int. J. Pharm. 3(4): 722-727.

Pugalenthi, M., V. Vadivel, P. Gurumoorthi, K. Janardhanan. 2004. Comparative nutritional evaluation of little known legumes, Tamarindus indica, Erythrina indica and Sesbania bispinosa. Trop. Subtrop. Agroeco. 4: 107-123.

Punna, R., U.R. Paruchuri. 2004. Effect of maturity and processing on total, insoluble and soluble dietary fiber contents of Indian green leafy vegetables. Int. J. Food Sci. Nutr. 55(7): 561-567.

Ramesh, T., C. Sureka, S. Bhuvana, V.H. Begum. 2015. Brain oxidative damage restored by Sesbania grandiflora in cigarette smoke-exposed rats. Metab. Brain. Dis. 450: 1-10.

Saifudin, A., A. Fadhilah, K. Tirtodiharjo, W.D. Melani, D. Widyasari, T.A. Saroso. 2016. Bioprospecting for antiStreptococcus mutans: the activity of $10 \%$ Sesbania grandiflora flower extract comparable to erythromycin. Asian Pac. J. Trop. Biomed. 6(9): 751-754.

Santosa, E., U. Prawati, Sobir, Y. Mine, N. Sugiyama. 2015. Agronomy, utilization and economics of indigenous vegetables in West Java, Indonesia. J. Hort. Indonesia. 6(3): 125-134.

Sathasivam, P., T. Lakshmi. 2017. Brine shrimp lethality assay of Sesbania grandiflora ethanolic extract - in vitro study. J. Adv. Pharm. Educ. Res. 7(1): 28-30.

Saura-Calixto, F.U. 2011. Dietary fiber as a carrier of dietary antioxidants: an essential physiological function. J. Agric. Food Chem. 59: 43-49.

Setiawan, E. 2013. The local wisdom by farmer in East Java: utilization of cultivated plant in intercropping system. J. Rekayasa. 6(2): 67-76. 
Setiawan, E. 2017. Studi etnobotani pemanfaatan tanaman sayuran di Kabupaten Pamekasan. J. Rekayasa. 10(1): 1-8.

Siddhuraju, P., A. Abirami, G. Nagarani, M. Sangeethapriya. 2014. Antioxidant capacity and total phenolic content of aqueous acetone and ethanol extract of edible parts of Moringa oleifera and Sesbania grandiflora. Int. J. Biol. Biomol. Agric. Food Biotechnol. Eng. 8(9): 1090-1098.

Sreerama, Y.N., V.B. Sashikala, V.M. Pratape, V. Singh. 2012. Nutrients and antinutrients in cowpea and horse gram flours in comparison to chickpea flour: evaluation of their flour functionality. Food Chem. 131(2): 462-468.

Tosh, S.M., S. Yada. 2010. Dietary fibres in pulse seeds and fractions: characterization, functional attributes, and applications. Food Res. Int. 43(2): 450-460.

Vinothini, K., M.S. Devi, V. Shalini, S. Sekar, R.B. Semwal, P. Arjun, D.K. Semwal.
2017. In vitro micropropagation, total phenolic content and comparative antioxidant activity of different extracts of Sesbania grandiflora (L.) Pers. Curr. Sci. 113(6): 1142-1147.

Wang, S.Y., C.T. Chen, C.Y. Wang. 2009. The influence of light and maturity on fruit quality and flavonoid content of red raspberries. Food Chem. 112(3): 676684.

Zhao, D., J. Tao, C. Han, J. Ge. 2012. Flower color diversity revealed by differential expression of flavonoid biosynthetic genes and flavonoid accumulation in herbaceous peony (Paeonia lactiflora Pall.). Mol. Biol. Rep. 39(12): 1126311275.

Zhu, F., B. Du, R. Li, J. Li. 2014. Effect of micronization technology on physicochemical and antioxidant properties of dietary fiber from buckwheat hulls. Biocatal. Agric. Biotechnol. 3(3): 30-34. 